\title{
The Right to Rebel: Social Movements and Civil Disobedience
}

\author{
Sergio Fiedler
}

\begin{abstract}
"Those who profess to favor freedom, yet deprecate agitation, are men who want crops without plowing up the ground. They want rain without thunder and lightening. They want the ocean without the awful roar of its many waters. This struggle may be a moral one; or it may be a physical one; or it may be both moral and physical; but it must be a struggle. Power concedes nothing without a demand. It never did and it never will." Frederick Douglass, African-American abolitionist
\end{abstract}

\begin{abstract}
A fundamental dimension of contemporary social movements is the use of civil disobedience, as means of both exerting mass pressure on the political system and as a process through which the participants of a social movement perceive and construct an alternative and autonomous democratic power. This article attempts to develop a political and ethical reflection about the transformative dimension and collective potential of civil disobedience drawing on the notions of the right to rebel and the performative.
\end{abstract}

As I write these pages, news reports from Peru announce that the government of that Latin American country has retreated from its attempt to pass laws authorizing transnational companies to exploit the riches of the Amazonia region, after local indigenous people organized a general strike and blockaded roads protesting against the potential negative impact on their communities ${ }^{1}$. These events are certainly part of a global trend where collective action and civil disobedience are having a key impact on government policies. In fact, the passage to the Twenty-First Century has been marked by the reemergence of mass social movements, whose actions and powerful critique of the market economy has had profound effects on the political imaginary of a new generation of activists, opening the road to significant political and social reforms in an important number of countries. Without any doubt, the mass protest against the World Trade Organization in Seattle in 1999, followed by the anti-summit protests in Davos, Toronto, Melbourne and Genoa among others, signaled the appearance of an anti-corporate movement whose militancy and carnivalesque diversity made a major contribution to the break up of the neoliberal 
consensus around the world (Juris 2008, pp. 61-97). Although the conservative turn provoked by $9 / 11$ and the "war against terror" undermined severely political possibilities, the rapid development of public opposition to the US invasion of Iraq meant a rapid return to mass political action, this time under the banner of anti-war activism, laying the ground for the weakening of neo-conservative hegemony in Washington.

In the South, particularly Latin America, the wave of change unleashed by social movements has been even more profound and radical. After decades of military dictatorship, neo-liberal economics and half-hearted transitions to liberal democracy, there have emerged reformist governments that to varying degrees maintain a close connection with the urban social movements that brought them to power. Although the implementation of social reforms in Venezuela, Argentina, Bolivia, Uruguay, Brazil, Ecuador, Nicaragua and El Salvador has not been exempt from new conflicts and antagonisms, including the development of mass movements by conservative forces in opposition to these reforms, Latin America seems to be definitively breaking-away from neo-liberalism. Instead, a new continental social democracy has emerged, that combines a greater presence of the State in economic decisions with the militant mobilization of a popular mass base, as illustrated by the urban movement that halted the military coup attempt to oust Hugo Chavez from power in 2002 (Robinson 2004, pp. 135-53).

The extent to which this reemergence of mass social movements generates a radical reshaping of the world capitalist order is still an open question. From the academic world, there have emerged a number of analyses and debates about characteristics and potentialities in this respect. While Hardt and Negri (2004) discuss them in terms of the notion of "multitude" and the formation of a "counter-empire", Ernesto Laclau (2007) prefers to speak of new forms of "populist interpellation". ${ }^{2}$ The transnational scope of these movements in the context of globalization also prompted neo-Gramscian scholars to sustain the idea of an emerging global historic bloc contesting the "Washington Consensus" (Rupert 2005). Others, following a Deleuzian perspective, see these collective processes as instances of radical multiplicity, lines of flight, and nomadism (Silva \& Browne 2006). Despite the strengths and weaknesses of each approach, they all seem to overlook the logics of social action by which these movements become the political inflection of a social 
antagonism. Such action centres on civil disobedience, as means of both exerting mass pressure on the political system and as a process through which the participants of a movement perceive and construct an alternative and autonomous democratic power.

It is possible to approach this question of civil disobedience from a number of perspectives. Within the liberal-democratic tradition, as pointed out by the classical essay on the subject written in 1849 by Henry David Thoreau, civil disobedience can be considered as a fundamental part of the right to rebel against unfair laws and tyrannical government. According to Thoreau, participation in the constitutional political process is often insufficient to prevent the application of unjust laws by governments, and disobeying the law becomes then a duty and a right as a form of exercising the freedom of the individual citizen as against the corrupting power of government (Marshall 1993, pp. 184-88).

In his book Theory of Justice (1978), John Rawls defines civil disobedience as non-violent public act that is against the law but is carried out with the goal of changing laws or the government program. Softening Thoreau's combative individualism, Rawls outlines three conditions under which civil disobedience can be considered a legitimate public action in the context of the liberal-democratic contract. In the first place, it is strictly necessary that all avenues of legal and institutional action are exhausted. Secondly, civil disobedience should be only used in explicit and concrete cases of injustice such as when liberal principles, like equality before the law, are under attack, and not simply in response to any type of unjust law or government practice. Finally, the act of civil disobedience should always be proportional to the transgression, and should never reach a point where it poses a threat to the functioning of the constitutional order (Rawls 1978, p. 405). While Jürgen Habermas (1985, pp. 95-116) tends to agree with Rawls in regard to these conditions, he gives civil disobedience a more central role in promoting public participation in the context of the intrinsic imperfections of liberal democracy. ${ }^{3}$ For him, civil disobedience is part of the process of rational deliberation and communication by which an argument or statement is put forward in the public sphere with the purpose of appealing to society's sense of justice, creating more legitimate legislation and modes of rational governance.

By giving a radical twist to these authors' liberal-democratic formulations, it is possible to argue that civil disobedience, as a dimension of the right to rebel against oppression, is not 
only a fundamental human right, but the most important human right we have. In fact, without acknowledging the existence of the right to rebel embodied in civil disobedience, the very idea of human rights ceases to make any sense. We need to remember that the dominant discourse of human rights emerged out of the mass rebellions of the American and French Revolutions. Within modern society, it was the exercise of the right to rebel as constitutive moment of a democratic subjectivity that opened the possibility for us today to contemplate the very notion of human rights as juridical principles organizing the political system. The right to rebel underwrites and creates the collective and political foundation for every Human Right to exist, its full exercise therefore becoming the only effective avenue of democratic defense when those rights are under attack. Certainly, in the context of the attacks on Human Rights often embedded in free trade agreements, the prosecution of the "war on terror" and torture, and when transnational military and economic organizations make decisions affecting the vast majority of people on the planet without creating avenues of public consultation (and in fact suppressing democracy and civil liberties), the right to rebel and civil disobedience becomes a central feature of mass social movements struggling for global justice. The examples, in this respect, are countless over the last decade: the ongoing mobilization of Zapatistas communities in Chiapas against military occupation, the disruption of economic summits by anti-corporate activists in different countries of the North, the occupation of highways and roads by Bolivian peasants against the privatization of water, and the mass occupation of high schools by students in Chile during May and June of 2006, among others. In contrast to the conception of civil disobedience developed originally by Thoreau, the adversary to be targeted by these acts of disobedience and rebellion is not simply a national government or law, but emerging forms of global sovereignty connecting and articulating the power of private corporation, global economic institutions (IMF, World Bank, and WTO) and the national state (Goodman 2002).

In this respect, it is necessary to recognize the inadequacies and limitations of the liberaldemocratic perspective on civil disobedience. By focusing on individual Human Rights within the context of the nation-state, liberal-democratic approaches often tend to obscure the fact that "unfair" and "unjust" laws function to benefit a transnational corporate elites seeking to control vital economic resources. It also fails to recognize that a complex network of institutions and ideologies politically support these "unfair" laws. To make 
sense of civil disobedience, not simply as an expression of liberal moral outrage, "unfair" laws need therefore to be understood in terms of the social antagonisms and power relations providing the structural foundation of their legal existence. They also need to be understood in terms of the institutions and ideologies designed to create the impression that we live in a peaceful and democratic society without fissures, contradictions or inequalities. Here the logic of civil disobedience is not simply about breaking the law and limiting the power of government, but deploying collective power in order to make the antagonisms that may be obscured and hidden within society, visible and legible to the population. In 2002 hundreds of demonstrators blockaded the Sydney headquarters of Australian Correctional Management, a company contracted by the Australian Federal Government to run refugee detention centres. The demonstrators denied people entry to the main building, but were not promoting violence so much as signifying, in both a physical and symbolic way, the violence of mandatory detention suffered by thousands of asylum seekers. Their action was aimed at highlighting, for a brief moment, the reality of the detention camps administered by this transnational company, in the "respectable" space of Sydney’s CBD. Moreover, acts of civil disobedience like this become real schools of political science. By making social antagonism and injustice visible before the eyes of broader society, people learn about their ability and power to work together and enact change collectively, as well as about the role of the official media, the police and government in managing or suppressing dissent.

Although making the antagonism between an oppressive social order and the multitude visible might not end up in a revolution, it might have important social and political repercussions. As Verity Burgmann argues (1993, p. 262), even the success of moderate demands and actions depends on groups of activists making "unreasonable" proposals. Civil disobedience is, therefore, about being realistic by demanding the impossible. As Zizek argues, what is truly real always lies within the impossible (Zizek 1999, p. 199). Civil disobedience is the radical gesture of bending the stick; "when the stick is bent in the wrong way -as it is the case today- it is necessary, in order to put the world back on track, to hold it and bend it in the opposite direction until the stick is right" (Althusser 1990, p. 210). From this point of view, civil disobedience is a political act which does not operate within the frame of the existing relation of forces, but as collective and subjective force which attempts to modify and subvert the very frame within which those relations of forces 
operate. Civil disobedience is to make a point by standing on the performative power of the outrageous, where the most unreasonable position becomes the only guarantee for the survival of the ethical act. Drawing on J.L. Austin (1976, p. 40) distinction between the constative and the performative dimensions of the speech act, it is possible to argue that the effectiveness of civil disobedience depends, first, on the ability to state demands or report a political situation of injustice to an audience (the constative), but also, second, and more important, an ability to perform an utterance that impels a political effect, changing the field of meaning of what is considered possible, so that the corporate and political elite in power is no longer perceived as undefeatable. ${ }^{4}$

In this respect, the new anti-corporate activist should perhaps draw inspiration from the figure of the refugee and the performativity of her collective disobedience. The refugee engages in a double act of civil disobedience. The first act of civil disobedience is refusing to submit to a situation of poverty and oppression by escaping the power of her own nationstate. In the age of terror and globalisation, mass migration in this respect has become a fundamental tool of resistance. But, for this act of rebellion to be politically meaningful, it needs to be completed by a second act of civil disobedience: demanding a more inclusive global system by challenging the borders and the privileges of the nation-states of the First World such as United States and Australia. Refugees and undocumented migrants, therefore, are not simply the passive victims of a system of exclusion; they are a truly democratic force constituting a new social landscape. Their suffering and their resistance form a clear example of civil disobedience: a globalisation from below by an undocumented multitude that, in its escape from the political and economic enclosures created by global capitalism, challenges the ideology of the nation-state by moving across national borders independently of state intervention and approval.

What a profound act of dignity and civility it was to bring down the fences of the refugee detention camp in Woomera, in middle of desert in the Easter Holiday of 2002, when dozens of the refuges in detention stormed out of the place with the assistance of demonstrators from outside. ${ }^{5}$ This action was extraordinary because it was the encounter of two vastly distinct and multiple cultural worlds creating a third space for intercultural communication that was far more legitimate and effective than the bland discourse of 
official multiculturalism. On the hand, there were the detainees; most of them men, women and children from Muslim background, who arrived to Australian coasts in overloaded boats after a long overland journey to Indonesia from the Middle East (Diken 2004). On the other hand, there were the young and cosmopolitan Australian activists from the inner city neighborhoods of Adelaide, Melbourne, Sydney and Brisbane, arriving to Woomera to show their support and solidarity with the asylum seekers. Here civil disobedience provided the communicative and democratic ground for an encounter among “others” separated not only by a national border but also by drastically different beliefs and lifestyles; and yet “others” who were capable of connecting at the margin by means of the acceptance and mutual recognition of the alterity and singularity of each in the struggle (Monson 2003). The bodies looked, talked and touched each other, breaking down the apparent unbridgeable barriers that separated them.

What Woomera 2002 highlighted, in this regard, is one of the most important dimensions of civil disobedience within the anti-corporate and anti war movement in different countries of the world: opening the possibility for the "enacted utopia" of the anti-statist and anticapitalist public sphere. Following Slavoj Zizek, it is possible to argue that civil disobedience is the radical political act where a world inclusive of many worlds is not simply a distant promise, but the suspension of the oppressive temporality of the existing social order through which the possibility of that new world manifests itself in the actual moment of civil disobedience. Civil disobedience is "the short circuit between the present and the future" where we are for a moment of our lives "allowed to act as if the utopian future were already at hand, just there to be grab" (Zizek 2002, pp. 558 - 59). In contrast to the serialized daily routines within a consumer society, civil disobedience is not another form of hardship or sacrifice that we need to undergo in order to achieve a "good" and "moral" society at the end of the road. Certainly, as it is often the case, civil disobedience exposes demonstrators to the violence of the State, involving a profound sense of collective responsibility, self-sacrifice and hardship, where what is dearest to us - our bodies- become weapons of resistance. However, unlike the corporeal self-sacrifice of the worker in the assembly line or the fundamentalist suicide-bomber for that matter, the hardship of civil disobedience is a sacrifice over which a living future of freedom and happiness already cast its shadow. Civil disobedience is the opportunity to open a space for communication with 
each other, to develop and forge political and social relations that are based on solidarity, collective reciprocity and absolute democracy, and not competition and greed. Civil disobedience is not about violence, but the gentleness and tenderness of a multitude that gathers before a common danger. In a society where we have to routinely commute between work and home in packed trains and buses without talking to each other, a collective act like this is a true moment of grace. After reading the often theological arguments of Walter Benjamin (1999) about social change, it becomes almost impossible not to see civil disobedience as some form of messianic and redemptive revolutionary event, where the action is not the lineal and causal result of an historical process, but an instant where time -as we know it- comes to stop and those oppressed are called to establish the reign of justice on earth.

The use of civil disobedience by the social movements marking the passage to the new Century has facilitated a profound a moment of rupture within the global neoliberal order. In a global context where the political is reduced to technical decision making, the performing bodies and affects involved in civil disobedience propel the formation of politics “proper”. According to Ranciere (2001), politics “proper” has to do with the irruption of the demos, the politization of those excluded from participation so that they become the general representatives of society as whole, destabilizing the functional and normative order of a social structure based on inequality and injustice. ${ }^{6}$ What civil disobedience marks thereby, as a moment of crisis through which the excluded obtains the hegemonic leadership of society, is the radical rupture between a terrain of politics limited to showing obedience for the law (including technical decision making) and the actual politics of democracy as an ongoing process of social change. From there that civil disobedience cannot be understood in terms of an action carried out by a rented crowd full of resentment. Civil disobedience is a democratic act carried out by a group of individuals inspired and radicalized by the possibilities of emancipation expressed in their own collective action. That is the reason why the disobedient is, even if only for a brief moment, already free while fighting for freedom. 


\section{Bibliography}

Agamben, G. 1995, Homo Sacer: Sovereign Power and Bare Life, Stanford University, Stanford.

Althusser, L. 1990, 'It is Simple to be a Marxist in Philosophy', Philosophy and the Spontaneous Philosophy of the Scientists and Other Essays, Verso, London.

Austin, J.L. 1976, How To Do Things With Words, Oxford University Press, Oxford. Benjamin, W. 1999, The Arcades Project, Harvard University Press, Cambridge.

Burgmann, V. 1993, Power and Protest: movements for change in Australian society, Allen \& Unwin, St Leonards, N.S.W.

Diken, B. 2004, 'From refugee camps to gated communities: biopolitics and the end of the city’, Citizenship Studies, vol. 8, no. 1, pp. 83-106.

Goodman, J. 2002, Protest and Globalisation: Prospects for Transnational Solidarity, Pluto Press Australia, Annadale.

Habermas, J. 1985, 'Civil Disobedience: Litmus Test for the Democratic Constitutional State', Berkeley Journal of Sociology, no. 30, pp. 95-116.

Hardt, M. \& Antonio Negri 2004, Multitude: War and Democracy in the Age of Empire, Penguin Press, New York.

Juris, J.S. 2008, 'Performing politics: Image, embodiment, and affective solidarity during anti-corporate globalization protests', Ethnography, vol. 9, no. 1, pp. 61-97.

Laclau, E. 2001, 'Can inmanence explain social struggles?' Diacritics, vol. 31, no 4, pp. 310.

Laclau, E. 2007, La Razón Populista, Fondo de Cultura Económica, Buenos Aires.

Marshall, P. 1993, Demanding the Impossible: A History of Anarchism, Fontana Press, London.

Monson, D. 2003, 'Woomera 2002 festival of freedoms: experiencing community in tragic recognition of the other', Journal of Australian Studies, no. 77, pp. 15-22.

Ranciere, J. 2001, Ten Theses on Politics, Theory and Event, vol. 5, no. 3, pp.1-10.

Rawls, J. 1978, A Theory of Justice, Fondo de Cultura Económica, México.

Robinson, W. 2004, 'Global Crisis and Latin America”, Bulletin of Latin American Research, vol. 23, no. 2, pp. 135-153.

Rupert, M. 2005, 'Reading Gramsci in an Era of Globalising Capitalism', Critical Review of International Social and Political Philosophy, vol. 8, no. 4, pp. 483-4

Scalmer, S. 2002, Dissent Events: protest, the media and the political gimmick in Australia, UNSW Press, Sydney.

Silva Echeto, V. \& R. Browne Sartori 2007, Antropofagias: las indisciplinas de la comunicación, Biblioteca Nueva, Madrid.

Thomassen, L. 2006, 'Within the limits of deliberative reason alone: Habermas, civil disobedience and constitutional democracy’ Australian Political Science Association Proceedings.

Zizek, S. 2002, ‘A plea for Leninist Intolerance’, Critical Inquiry, vol. 28, no. 2, pp. 55859.

Zizek, S. 1999, The Ticklish Subject: the absent centre of political ontology, Verso, London. 


\section{EndNotes}

1 'El Gobierno cede ante los indígenas', June 16, 2009 , http://www.elcomercio.com

${ }^{2}$ For an interesting critique on the notion of multitude developed by Hardt and Negri, see Laclau 2001.

${ }^{3}$ In his discussion on the subject in his book Between Norms and Facts, Habermas sustains that: "the justification of civil disobedience relies on a dynamic understanding of the constitution as an unfinished project. From this long-term perspective, the constitutional state does not represent a finished structure but a delicate and sensitive - above all fallible and revisable - enterprise, whose purpose is to realize the system of rights anew in changing circumstances, that is, to interpret the system of rights better, to institutionalize it more appropriately, and to draw out its contents more radically. This is the perspective of citizens who are actively engaged in realizing the system of rights. Aware of, and referring to, changed contexts, such citizens want to overcome in practice the tension between social facticity and validity". Cited in Thomassen, 2006.

${ }^{4}$ For more on the politics of performative protest see Scalmer, 2002.

${ }^{5}$ Drawing on Agamben's notion of the Homo Sacer, Diken describes the situation in Woomera as follows: "Enter the camp Woomera, the infamous detention center in Australia. A detainee says: 'when we came first to Woomera, we didn't believe we were in Australia ... Because the things that happened - they wouldn't happen in Australia. It must be another country' (quoted in Campbell, 2002:26). 'Woomera is another country', adds Campbell, commenting on his interviewee's utterance. However, the point is rather that Woomera, established and run by Australian authorities alone, is effectively a frustrating zone of indistinction between inside (law) and outside (unlaw), a space in which the link between localization and order breaks down, a space that can materialize only when exception becomes the rule. It is the location of the unlaw within law in the form of an exception that turns Woomera into an unbounded space. Hence the confusion whether it is inside or outside Australia" (Campbell, 2002:26).

${ }^{6}$ From this perspective, Ranciere argues that "to identify politics with the exercise of, and struggle to possess, power is to do away with politics. But we also reduce the scope of politics as a mode of thinking if we conceive of it merely as a theory of power or as an investigation into the grounds of its legitimacy. If there is something specific about politics that makes it something other than a more capacious mode of grouping or a form of power characterized by its mode of legitimation, it is that it involves a distinctive kind of subject considered, and it involves this subject in the form of a mode of relation that is its own” (Raciere 2001). 